\title{
Succession Analysis in Family Business \\ (Case Study at PT. BJE)
}

\author{
$\mathrm{OH}$, Retno Sri Wahyuningsih \\ Soegijapranata Catholic University \\ retnosriw88@gmail.com \\ Agatha Ferijani \\ Soegijapranata Catholic University \\ feri.unika@gmail.com
}

\begin{abstract}
This study aims to analyze the family business succession process carried out by PT. BJE in the election of son-in-law as the business successor. To understand the selection process, a succession analysis was carried out through the seven stages of the Seven-Point Star Model. The research method uses descriptive qualitative with a case study phenomenology approach. This study used primary and secondary data obtained by means of semi-structured in-depth interviews, participatory observation, and company documentation. The results showed that the stages of the Seven-Point Star Model succession planning had not yet been fully implemented by PT. BJE.
\end{abstract}

Keywords: family business, succession decisions, Seven-Point Star Model.

\section{INTRODUCTION}

In Indonesia, family business plays a significant role in supporting the economy and providing employment opportunities for the community (Lucky, Minai, \& Isaiah, 2011; Randerson, 2016). A survey conducted by the Statistics of Indonesia (2007) showed that in $2016,90.95 \%$ of 48,929,636 companies in Indonesia were family owned companies (Wahjono, 2011). This is also supported by the Price Waterhouse Cooper Indonesia's research (PwC, 2014) that found more than $95 \%$ of businesses in Indonesia are family businesses and they contributed 25\% to the national Gross Domestic Product (GDP). Therefore, sustainability of family businesses is crucial for Indonesia's economic growth.

The phenomenon faced by family companies in order to maintain their business sustainability focuses on the desire of the founder to involve the next generation in the business 
activities (Susanto, 2005). Nevertheless, maintaining business over time requires the right people for the right jobs in the right place and at the right time to do the right things to get the right results (Rothwell, 2010). One way a family company can sustain a business is to do succession planning (Boyd, Royer, Pei, \& Zhang, 2015; Short, Sharma, Lumpkin, \& Pearson, 2016; Wang, 2008) intended to the next generation of family members (Walsh, 2011).

With succession planning, talented and successful potential successors can be identified (Rothwell, 2010) and those potentials (Maciel, Ramos, Aguilar, \& Reyna, 2015; Mokhber et al., 2017; Steier, Chua, \& Chrisman, 2009) who are competent and able to manage the company can bring progress and development of the company in the future (Susanto, 2005). According to Rothwell (2010), succession planning needs to go through seven stages called seven-point star model which include to make the commitment, to assess present work/people requirements, to appraise individual performance, to assess future work/people requirements, to assess future individual potential, to close the development gap, and finally to evaluate the succession planning program.

This research focuses on the succession process carried out by a family business named PT. BJE located in Semarang. PT.BJE that is engaged in the culinary sector was established in 1981. He chose a son-in-law as the successor of the family business. This study analyzes the process of implementing succession carried out by PT. BJE in the election of son-in-law to continue the family business. The benefits of this research are expected to provide insight for family companies in selecting and preparing their successor.

\section{LITERATURE REVIEW}

\section{Family company}

According to Ward and Aronoff (2002) in Susanto (2005), family company consists of two or more family members who oversee the company's finances. PWC (2014) defined 
family business as a company whose majority of the voting rights are in the hands of the founder or the person who acquired the company, such as spouse, parent, child or heir.

\section{Succession Planning and Management}

Succession planning and management $(\mathrm{SP} \& \mathrm{M})$ is the process to ensure stability of key positions tenure so that in the event of a vacancy, management has prepared a replacement. The process is an effort made to ensure sustainability of effective performance in organizations, divisions, departments, or work groups by providing development, replacement, and application of strategies for key positions over time (Rothwell, 2010).

\section{The Seven-Point Star Model Succession Process}

Systematic succession planning and management need to go through stages called the Seven-Point Star Model (Rothwell, 2010).

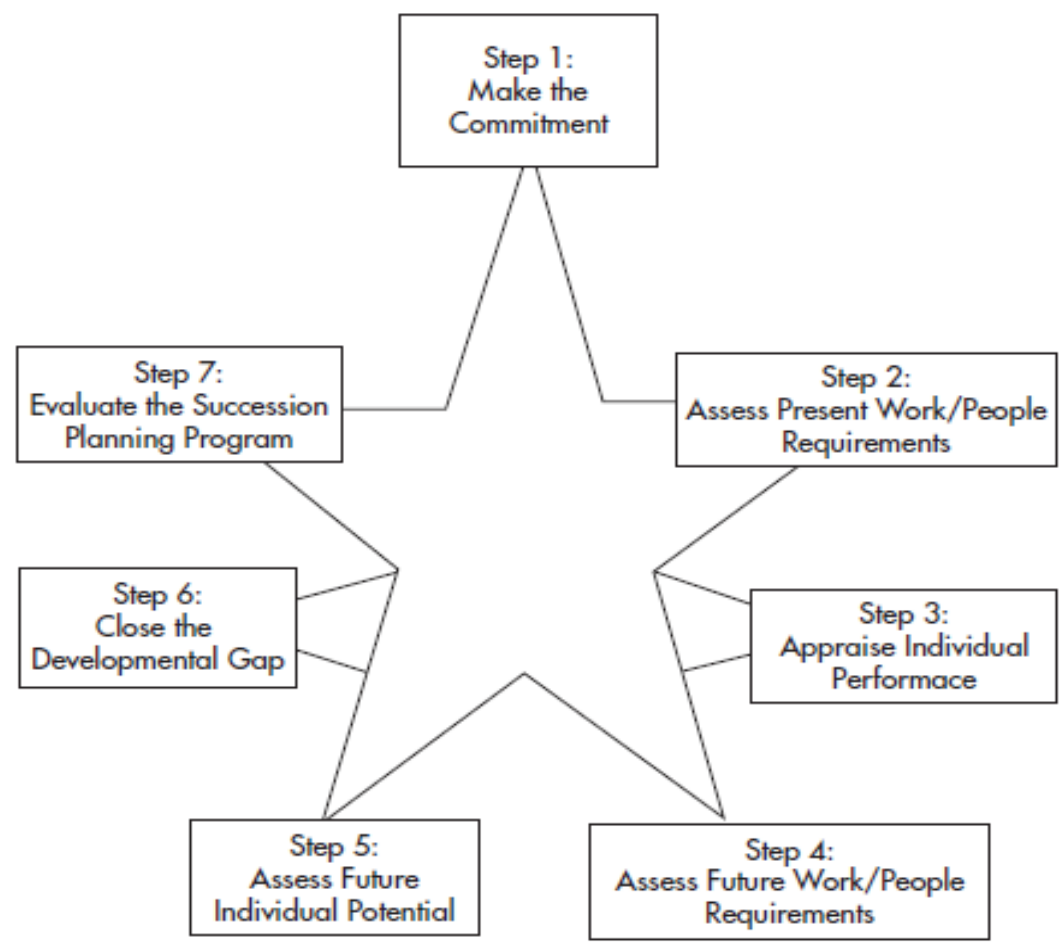

Figure 1. Seven-Point Star Model (Rothwell, 2010)

1. Make the commitment. Decision makers in the company must commit to the systematic of SP\&M. 
2. Assess present work/people requirements. Decision makers determine the position or key individual to be replaced by which SP\&M aims. Work requirements must be made so that the successor can prepare the attributes according to the company expectations in terms of hard skills and soft skills.

3. Appraise individual performance (performance appraisal). The process determines how well individuals meet their work requirements.

4. Assess future work/people requirements. Decision makers assess work needs and competencies in the future according to the strategic direction of the organization so that future leaders can be prepared.

5. Assess future individual potential. A systematic process for assessing the potential of individuals to make work changes that gives basis for determining training, education, and development to promote individual progress.

6. Close the developmental gap. Establish an ongoing program to close the leadership development gap between what successors can do and what they must do using planned training, education, and development.

7. Evaluate the succession planning program. Evaluate succession planning to assess how it is performing. The results from this final stage can be used to create a program of continuous improvement and maintain a systematic succession commitment.

\section{METHOD}

This research used descriptive qualitative research method to reveal, explore, and describe aspects related to the problem and research objectives through the process of interviews, field notes, photographs, documentation, and so on (Moleong, 2007). This research used phenomenology approach in terms of a case study to reveal awareness and motives of the 
incumbent in the decision making of family business succession that underlies the choice of son-in-law to be the successors of family business.

\section{Research Informant}

Key informants from PT. BJE is the founder who is the incumbent, the successor, 2 employees who have a position and are well acquainted with the family, namely the secretary and the operational manager.

\section{Data Collection Technique}

The data used in this study are primary data obtained directly from the original source (not through intermediary media). Data were gathered from interviews with key informants and participatory observation. Secondary data in the form of background, vision, mission, and structure of PT. BJE is obtained from the documentation of the company.

\section{Data Validity Techniques}

To determine the validity (trustworthiness) of the data, examination techniques are carried out: credibility test through triangulation of interview data; transfer testing through searching and gathering empirical research from such as journals in relevant context; dependability test by consulting or reading scientific references, testing conformability through consultation with a thesis supervisor; and an audit trail by tracking back field notes, data collection techniques, and data analysis techniques that have been carried out (Moleong, 2007).

\section{Data Analysis Technique}

This study used analytical techniques with an interactive analysis model revealed by Miles and Huberman (Fatchan, 2011) through the stages of data collection, data reduction and categorization, data display, and decision making (conclusion drawing). 


\section{RESULTS AND DISCUSSION}

The founder of PT. BJE have three daughters and the son-in-law of his first child was chosen as the successor of PT. BJE.

\section{The Succession in Seven-Point Star Model}

1. The make-the-commitment phase is demonstrated by the successor's commitment to join the business immediately after marrying the first daughter.

2. At the assess-present-work/people-requirement stage, the successor was given a position in the finance department to take care of the company's finances.

3. The stage of individual performance appraisal is shown by verbal advice given by the founder to the successor.

4. The assess-future-work/people-requirement stage is demonstrated by the founder's desire to continue the business to the generation of his grandchildren.

5. At the assess-future-individual-potential stage The successorhad been appointed as a director and held great control over the business in accounting, finance, and corporate taxes.

6. At the close-the-developmental-gap stage, Mr. Daniel provided trainings through direct mentoring during meetings and discussions, and gave opportunity for The successorto manage and make decisions. Mr. Daniel would assist if The successorencuntered difficulties.

7. The evaluate-the-succession-planning-program stage is demonstrated by improvements in accounting, finance, and taxation to become more professional.

From table 1, it is known that PT. BJE has carried out the succession stage of the Seven-Point Star Model by $61.54 \%$ in the selection of business successors. 
Table 1. Checklist for the Implementation of the Seven-Point Star Model Succession at PT. BJE

\begin{tabular}{|c|c|c|c|}
\hline No & Stages & Indicator & Implementation \\
\hline \multirow[t]{2}{*}{1} & \multirow[t]{2}{*}{$\begin{array}{l}\text { Make The } \\
\text { Commitment }\end{array}$} & $\begin{array}{l}\text { a. Successor is committed to running a } \\
\text { family business }\end{array}$ & $\sqrt{ }$ \\
\hline & & b. Succession is described in writing & $x$ \\
\hline \multirow[t]{2}{*}{2} & \multirow{2}{*}{$\begin{array}{l}\text { Assess Present } \\
\text { Work/People } \\
\text { Requirement }\end{array}$} & c. The key position for successor is set & $\sqrt{ }$ \\
\hline & & $\begin{array}{l}\text { d. There are work requirements that must } \\
\text { be fulfilled by the successor }\end{array}$ & $\sqrt{ }$ \\
\hline \multirow[t]{2}{*}{3} & \multirow{2}{*}{$\begin{array}{l}\text { Appraise } \\
\text { Individual } \\
\text { Performance }\end{array}$} & e. Successor performance appraisal & $\sqrt{ }$ \\
\hline & & $\begin{array}{l}\text { f. A written, structured, and clear } \\
\text { successor performance assessment }\end{array}$ & $\mathbf{x}$ \\
\hline \multirow[t]{2}{*}{4} & \multirow{2}{*}{$\begin{array}{l}\text { Assess Future } \\
\text { Work/People } \\
\text { Requirement }\end{array}$} & $\begin{array}{l}\text { g. There is a plan that the successor } \\
\text { wants to achieve }\end{array}$ & $\sqrt{ }$ \\
\hline & & $\begin{array}{l}\text { h. There are work requirements that must } \\
\text { be fulfilled by successors in the future }\end{array}$ & $x$ \\
\hline 5 & $\begin{array}{l}\text { Assess Future } \\
\text { Individual } \\
\text { Potential }\end{array}$ & $\begin{array}{l}\text { i. There is an assessment of the } \\
\text { successor's development in meeting } \\
\text { future job requirements }\end{array}$ & $\sqrt{ }$ \\
\hline \multirow[t]{2}{*}{6} & \multirow{2}{*}{$\begin{array}{l}\text { Close The } \\
\text { Developmental } \\
\text { Gap }\end{array}$} & $\begin{array}{l}\mathrm{j} \text {. There is a guidance process from the } \\
\text { incumbent to the successor }\end{array}$ & $\sqrt{ }$ \\
\hline & & $\begin{array}{l}\mathrm{k} \text {. There are formal training, education } \\
\text { and development programs for } \\
\text { successors }\end{array}$ & $x$ \\
\hline
\end{tabular}




\begin{tabular}{|c|c|c|c|}
\hline \multirow[t]{2}{*}{7} & \multirow{2}{*}{$\begin{array}{l}\text { Evaluate The } \\
\text { Succession } \\
\text { Planning Program }\end{array}$} & 1. Evaluation of succession programs & $x$ \\
\hline & & $\begin{array}{l}\text { m. Management of company turn better } \\
\text { since the successor was involved }\end{array}$ & $\checkmark$ \\
\hline \multicolumn{2}{|c|}{ Percentage of succession } & do 8 out of 13 indicators & $61,54 \%$ \\
\hline
\end{tabular}

\section{CONCLUSIONS AND RECOMMENDATIONS}

\section{Conclusion}

From the results of the analysis, the researchers concluded that PT. BJE has not gone through the seven stages of the Seven-Point Star Model:

1. In the first step - make the commitment - the family business was committed to running the business professionally by involving future generations who really want and are able to manage the business. However, the succession plan has not yet been officially described and written.

2. The Second stage - assess present work/people requirements - refers to the key position is the director who would be prepared to become the successor of the business. The successor has the ability to handle management, accountancy, finance, and corporate taxes.

3. In relation to the third stage - appraise individual performance - assessment of successor performance was done verbally by the incumbent through direct communication, but there were no clear indicators of successor performance evaluation.

4. In the fourth stage - assess future work/people requirements - it reveals that expectation to continue the business from generation to generation ended at the son-in-law, but work targets or specific requirements of the future successor had not set yet. 
5. The fifth stage - assess future individual potential - indentifies the successor has considerably high potential to manage the business but he still needs to continuously learn and practice.

6. In the sixth stage - close the developmental gap - development of the successor was done through direct mentoring and supervising from the incumbent. However, there was no formal and planned training, education and development program for the successor.

7. In the seventh stage - evaluate the succession planning program, there had been no evaluation of the implementation of the succession process. Since the successor joined he family business, he had brought positive changes in the management in which bookkeeping, finance, and corporate taxation are to be more open.

\section{Theoretical Implications}

The selection of a family business successor needs to consider the family's circumstances. Since there is no desire from the three of incumbent's daughters to continue the family business, there is a need to consider the selection of successors outside the family members. Selection potential candidates must be based on their interests and abilities that meet the criteria suitable with the family business.

\section{Managerial Implications}

PT. BJE did not do some stages in the business succession process. However, the research found that the process of selecting sons-in-law as the business successor of PT. BJE can be a consideration to assist family businesses in choosing successors outside the family members to maintain sustainability of the family business in the future.

\section{Future Research}

Some suggestions for next researchers are:

1. Similar research can be conducted to many and diverse businesses to get broader results representing various business fields. 
2. Future research must include a number of variations or differences such as in company size, number of owners, and whether succession takes place from the first, the second or between later generations.

\section{REFERENCES}

Boyd, B., Royer, S., Pei, R., \& Zhang, X. (2015). Knowledge transfer in family business successions: Implications of knowledge types and transaction atmospheres. Journal of Family Business $\quad$ Management, $\quad 5(1), \quad 17-37$. https://doi.org/http://dx.doi.org/10.1108/MRR-09-2015-0216

Fatchan, H. A. (2011). Metode Penelitian Kualitatif. Jenggala Pustaka Utama.

Lucky, E.-O.-I., Minai, M. S., \& Isaiah, A. O. (2011). A conceptual framework of family business succession: bane of family business continuity. International Journal of Business and Social Science, 2(18), 106-113. http://www.ijbssnet.com/journals/Vol_2_No_18_October_2011/15.pdf

Maciel, A. S., Ramos, M. I. de la G., Aguilar, J. L. E., \& Reyna, J. M. S. M. (2015). The influence of family relationships in the succession: A factorial analysis of Mexican enterprises. Journal of Family Business Management, 5(2), 238-256.

Mokhber, M., Gi, T. G., Rasid, S. Z. A., Vakilbashi, A., Zamil, N. M., \& Seng, Y. W. (2017). Succession planning and family business performance in SMEs. Journal of Management Development, 38(3). https://doi.org/10.1108/02621710210417411

Moleong, L. J. (2007). Metodologi penelitian kualitatif ed. rev. REMAJA ROSDA KARYA. http://lib.unika.ac.id/index.php?p=show_detail\&id=34477\&keywords=moleong

PwC. (2014). Survey Bisnis Keluarga 2014, Indonesia (Issue November). http://www.pwc.com/id/en/publications/assets/indonesia-report-family-business- 
survey-2014.pdf

Rothwell, W. J. (2010). Effective Succession Planning: Ensuring Leadership Continuity and Building Talent from Within (4 Edition). Amacom.

Short, J. C., Sharma, P., Lumpkin, G. T., \& Pearson, A. W. (2016). Oh, the Places Well Go! Reviewing Past, Present, and Future Possibilities in Family Business Research. Family Business Review, 29(1), 11-16. https://doi.org/10.1177/0894486515622294

Steier, L. P., Chua, J. H., \& Chrisman, J. J. (2009). Embeddedness Perspectives of Economic Action Within Family Firms. ENTREPRENEURSHIP THEORY and PRACTICE, $1157-1167$.

Susanto, A. . (2005). World Class Family Business. Quantum Bisnis \& Manajemen (PT Mizan Pustaka). https://books.google.co.id/books?id=pJ58TZR40ckC\&printsec=frontcover\&hl=id\&s ource=gbs_ge_summary_r\&cad $=0 \# \mathrm{v}=$ onepage $\& \mathrm{q} \& \mathrm{f}=$ false

Wahjono, S. I. (2011). Suksesi Internal Bisnis Keluarga Untuk Penguatan Ekonomi Nasional Menghadapi Persaingan Bebas. International Standard Book Number, Juni, 16-35.

Walsh, G. (2011). Family Business Succession: Managing the All Important Family Component. In Family Business Succession.

Wang, W. (2008). Chinese Family Business and Issues of Succession and Human Resource Management. 